\title{
EMPOWERED PATIENT AUTONOMY IN THE NETWORK IN THE SELECTED AREA OF THEORETICAL REFLECTION AND EMPIRICAL ANALYSIS
}

\begin{abstract}
The aim of the article is to perceive the understanding of autonomy by conscious, empowered patients through an awareness of responsibility for their own health and knowledge of their rights. This perception was made by analysing their statements published in 16 online medical forums and portals, which referred to the components of autonomy. One hundred and twenty-seven posts qualified for qualitative analysis. Based on the research findings, it was concluded that the authors of the posts (intuitively) properly identified autonomy (although they did not use this notion as such), paying attention to principal, formative qualities and inherent rights. They identify these qualities based on the course and characteristics of interactions between patients and healthcare practitioners (exposing their deficits), within the context of participants' rights and duties as well as their opinions about physicians' qualifications and desired (mainly soft) competences.
\end{abstract}

Keywords: autonomy, empowerment, perception of empowerment, empowered patient, patient online, network, qualitative analysis.

\section{Introduction}

Much has been written about the role of autotelic values in human life. It is also of utmost importance that they be respected in medical relations, mainly physician-patient interactions. The undertaken research focuses on analysing con-stituent elements of autonomy as perceived by a special group of patients referred to as "empowered patients".

It is worth pointing out at the outset that a personal, dignified and autonomous approach to a human being should not be determined by legislative decisions, ${ }^{1}$

* Prof., PhD, Department of Sociology of Politics and Morality, Institute of Sociology, University of Łódź, ul. Rewolucji 1905 r. 41/43, 90-214 Łódź, e-mail: alicja.formejster@uni.lodz.pl

${ }^{1}$ Art. 23 of the Civil Code, according to which intimacy and personal dignity constitute personal rights of a human being; Art. 20-22 of the Patient Rights and the Patients Ombudsman Act, which obliges healthcare professionals to behave in such a way as to ensure that the patient's dignity and intimacy are respected; Art. 36, section 1 of the Act on Doctor and Dentist Professions, which 
although this form of safeguard is applied in the context of healthcare. Nor should axionormative interpretation be decisive, although respect for the right to intimacy and personal dignity is enshrined in patient rights, which are included in the principles and duties of medical professional ethics (Medical Code of Ethics: Art. 120). As with most interactions, a dignified, personal and autonomous approach to a human being is part and parcel of medical care. And it is up only to the participants in this interaction to ensure that these values are actually respected. Indeed, these values become particularly important in the course of medical interactions, in which there is an inherent lack of symmetry between participants. Further considerations address relations between physicians and "weaker", dependent people, suffering from temporary or chronic ailments, or those whose diagnosis and course of treatment are hampered by systemic, diagnostic or financial constraints. Therefore, it seems all the more important to continuously monitor the course of these interactions, to study the needs and feelings of patients, and to emphasise the importance of respect for fundamental, autotelic human rights.

Irrespective of why a relationship with a physician was initiated, patients expect respect for their autonomy and inherent subjectivity, which fosters the formation of the expected empathic attitude. The empathic attitude presupposes understanding of the will, feelings, experiences and the entire life situation of another person without identifying oneself with that person, which allows for objective assessments and conclusions (cf. Aring 1958: 447). It is noteworthy that "empathy is always a beneficial relationship in contact between a physician and patient" (Gaertner 1997: 40). Empathic behaviour is beneficial not only to the patient seeking support in a difficult situation but also for a physician when at the crossroads between adopting a paternalistic attitude towards the patient or respecting the autonomy of their choices. At the same time, the humanisation of the medicine movement calling for the holistic treatment of a person seeking medical help or advice also emphasises that it is the individual, subjective approach and special care for the patient that should constitute the highest value in the undertaken treatment.

The humanistic, empathic attitude of the medical community to patients entails a change in people's attitudes towards themselves: on the one hand, they feel a greater need to exercise their sense of freedom, while on the other their sense of responsibility for themselves decreases. They want to be free and at the same time expect someone else to take over part of the responsibility. With regard to the patient-physician relationship, it can be asserted that patients want medical care to fulfil their expectations and at the same time require that the physician involves them in making important decisions related to their health.

imposes an obligation on all physicians to respect the dignity of persons using medical services. Furthermore, according to para. 3 of this article, a healthcare professional is obliged to ensure that other medical personnel observe the principle of respect for dignity and intimacy when dealing with a patient. 
It has therefore been intriguing to encounter answers to the following questions: how do empowered patients - that is, those equipped with knowledge, conscious of their role, aware of their rights, in control of decisions that influence their health, and motivated to take responsibility for their own health ${ }^{2}$ - understand autonomy? How does respect for autonomy manifest in contacts with physicians (in their perception)? Is their online activity of this type (unaffected by outside influence)?

\section{Moral philosophy as a compatible part of healthcare}

From a moral point of view, the principles of medical ethics are grounded in universally binding ethical norms and specify them in more detail (Beauchamp, Childress 1996: 112). It can be said that the norms of medical ethics derive from the principles of universal ethics, rather than being a part of it (Ossowska 1963: 366). Hence this entails that, firstly, behaviour that is not acceptable in a relationship between a non-physician and non-patient is inadmissible in a physicianpatient relationship; and, secondly, physician-patient relations must not be in conflict with universally accepted principles of general ethics. However, it is the subjective dimension of the scope and hierarchy of moral norms accepted by the physician and the patient that is noteworthy.

In axionormative terms, the pillar of professional medical care is respect for the patient's dignity and the principle of subjective treatment (i.e. recognition of them as a specific, single, unique Individual). These values are of particular importance in the context of a physician-patient encounter, since they constitute an immanent part of the diagnostic and, later on, therapeutic procedure. Dignity, on the other hand, can be analysed in the context of different fields of science; in semantic terms, it means "the feeling, awareness of one's worth, self-respect, honour, pride" (Szymczak 1988: 673). "In law, human dignity is a fundamental issue, since respect for it is the starting point for the recognition of each person" (Kubiak 2016: 174). Many legal medical acts mention dignity as an essential value of universal importance that must be respected by all healthcare service providers. ${ }^{3}$ Physicians' legal obligations ${ }^{4}$ also include the obligation to respect human dignity and the obligation to ensure that other medical personnel observe the principle of respect for human dignity (Kubiak 2016: 174). The deontological, axionormative, duty-based context of healthcare as well as medical ethics also refer to this fundamental value as immanent in the process of providing care to a patient (Medical Code of Ethics: Art. 3, 12, para. 1).

2 The author's original proposal to define attributes of the empowered attitude.

3 See Art. 20-22 of the Patient Rights and the Patients Ombudsman Act as of November 6, 2008 (Journal of Laws of 2009, No. 52, item 414, as amended; consolidated text, Journal of Laws of 2016 , item 186 , as amended).

${ }^{4}$ Art. 36, sections 1 and 3 of the Act on Doctor and Dentist Professions as of December 5, 1996 (consolidated text, Journal of Laws of 2017, item 125). 
Having insight into specific needs of patients, medical professionals should strive to respect the patient's dignity and subjectivity (inscribed in dignity) "at any cost". A relationship filled with empathy, compassion and care for another person is impossible without recognition of the value of human subjectivity. And a meeting between a physician and a patient wherein the latter is always the subject of the interaction should be characterised by such attributes.

\section{Autonomy, the proposed scope of meaning}

Provided that autonomous action is characterised by conscious decision-making, without coercion, persuasion or manipulation, but is not entirely independent of external influence, it seems justified to assume that patients described as empowered are individuals who make decisions autonomously and who recognise autonomy as an important value.

Autonomy can be defined and understood as

individual freedom, the right to decide about oneself, individual sovereignty, independence, exercise of one's rights, independent establishment of moral principles, individuality, taking responsibility for one's own affairs, resilience to other people's influence, being true to oneself, being oneself, honesty, authenticity, etc. (Łuków, Pasierski 2014: 145).

Autonomy can also be described as a capacity or characteristic, right or value. Autonomy can refer to both actions and persons: "Sometimes autonomy describes actions and sometimes individuals" (Łuków, Pasierski 2014: 145).

The etymological context of this notion derives from the word autos (self, own, independent) and nomos (law, norm, government) and means self-determination, self-government, independence, setting standards for oneself (cf. Now acka 2005: 24; Kalisiewicz 1995: 291). The notion of autonomy is closely linked to other terms in moral philosophy such as agency, responsibility and paternalism. This is due to the consequences of treating an individual as an empowered person. Only an autonomy person can be considered to be in charge of a given act, and only such a person can be held responsible for committing a given deed. Paternalistic interference in an autonomy person's decision-making requires justification: "the more autonomy a given person is, the stronger this justification must be" (Górski 2012: 2). It is precisely paternalism that treats people as inert and denies them the right to self-determination, which is the main enemy of individual autonomy (Bujny 2007: 18). Medical paternalism is in clear opposition to the fulfilment of and respect for the principle of the patient's autonomy (Wichrowski 1992: 17). Although the aim of paternalistic actions is the patient's well-being, there is no doubt that it forces the individual to fully subdue themselves to the physician's decisions and actions (Brzeziński 2002: 45).

The principle of respect for autonomy is treated as an obvious and fundamental moral principle that constitutes one of the fundamentals of contemporary medical 
ethics, and is mentioned alongside the principles of non-maleficence, beneficence and justice. The principle of respect for autonomy recognises the individual's right to hold opinions, make choices and act according to their values and beliefs. This principle requires that the ability of the individual to make autonomous choices, to overcome fears and other obstacles undermining autonomy be maintained, while respect for the autonomy of others consists in treating them in a way that enables them to act autonomously (cf. Beauchamp, Childress 1996: 134).

From a different perspective, if the phrase "the patient's ability to act autonomously" were to be replaced by "the patient's ability to give informed consent", then the principle could be adopted that the lesser or greater the ability of a person to act autonomously, then the lesser or greater, respectively, is that person's ability to give informed consent to the proposed actions. Although there is no clear definition of informed consent, this does not mean that its elements cannot be identified (see also: Szewczyk 2009: 105-149). Informed consent consists of a series of actions that are inextricably linked to the maintenance of the patient's independence, based on the necessary conditions to be met in order to maintain autonomy. It is a deliberate, conscious action, without influence of external factors determining the patient's deeds (Atras, Marczewski 2004: 350).

Ultimately, it must be assumed that full implementation of the principle of respect for the patient's autonomy is a kind of ideal state (type) at which one should aim and that cannot be fully achieved. Therefore, respect for the patient's autonomy entails dealing with individual cases and setting a benchmark for the patient's essentially autonomous actions and decisions, although they do not fully meet the conditions of thorough insight and the absence of external influence (Faden, Beauchamp 1986: 240, after: Nowacka 2005: 28).

Given that empowered patients are recognised as autonomous subjects empowered through awareness of their responsibility for their own health and knowledge of their rights, it is worthwhile analysing and reflecting on the nature of their online activity (which is an inherent attribute of empowered attitudes). All the more so, since the development of online media has enabled quick access to various sources of knowledge that patients are looking for and are increasingly willing to share and consult with physicians. Patients want to be better informed and it is increasingly easy for them to obtain necessary knowledge (Miller, Washington 2016). So who are the empowered patients?

\section{The main assumptions of the concept of empowerment}

Patients have become increasingly active online $(47.7 \%$ of Poles search the Internet for information about diseases, treatment and physicians (Business Insider 2020). Health managers talk with increasing frequency about a new era of the patient, the era of the empowered patient. This is an ("empowered", 
"independent") patient co-responsible for their health thanks to having gained information and enriched their knowledge of diseases, healthy lifestyles, ${ }^{6}$ and ways to navigate through the increasingly complex structure of the healthcare system. Such a patient wants to be a partner in the process of treatment and is consciously involved in changing their own lifestyle and demands the right to their own, free choices.

If (quoting health managers) we were to call today's patient an empowered patient (although this is certainly a far-reaching generalisation), that would mean that, on the whole, they are well-educated, have access to medical knowledge and preliminary analysis of their health condition, and often carry out self-diagnosis on Internet forums and medical portals (e-diagnosis). The Polish empowered patient is aware of their rights, is empowered by their knowledge, has increasingly high expectations, and raises the bar for medical staff. Such a patient tends to control their health online and manage it online. In this consumerist model of healthcare, they are able to define their needs and take responsibility for their actions and decisions. This is a patient who is to be satisfied with the medical service (Salmon 2002: 25).

The main assumptions behind the concept of empowerment imply a change in the patient's profile. One should not impose anything on such a patient. They themselves should want to change their own attitude towards their health and disease prevention and should be involved in making it effective. It is the patient themselves who should want to exercise their freedom of choice, which is a manifestation of empowerment. In this context, patients are described as consumers who have the right to make their own choices. The patient should want to be aware, and should want to have control over their own health, but also over the healthcare system.

The scope of meaning of the term "the empowered patient", the patient empowered by knowledge, may, however, be defined differently, depending on who describes such a patient. Most frequently, the notion is applied to emphasise the particular importance of patients having greater control over their health and healthcare. However, WHO defines empowerment as a process through which people gain greater control over decisions and actions affecting their health (WHO 1998; Hohn 1998). Four fundamental components of the process of empowerment or enhancement of patient autonomy are:

${ }^{5}$ One can find translations of an empowered patient as a "patient-partner", "patient-decision-maker" or "entitled patient" on the website of the "MY Pacjenci" (US Patients) foundation.

${ }^{6}$ A representative, nationwide survey entitled Poles' Healthy Lifestyle conducted by TNS Polska for Headlines from 12.03.-10.04.2012 revealed that Poles had relatively detailed knowledge of a healthy lifestyle identifying it mainly with diet and physical activity. Respondents believed that in order to live a healthier life, one should first of all give up stimulants and addictions (e.g. cigarettes and alcohol) and avoid unhealthy fast food. A decision to switch to a healthier lifestyle is usually made independently or together with a physician or family member. Patients make this decision because they want to change themselves or because they feel bad. Most Poles declare that they use public healthcare although some of them choose specialist private healthcare. 
1) recognition of the patient's role by the patient (Lyons 2007: 140-142);

2) sufficient knowledge to be able to engage with their "healthcare provider" (Coulter, Entwistle, Gilbert 1999: 318-322);

3) self-efficacy; the effectiveness of the patient's actions, defined as the belief that they have the ability to achieve desired outcomes (Gallagher 2012a; Gallagher 2012b). Individuals convinced of their efficacy, i.e. having the ability/competences to achieve their goals, are more likely to engage in such behaviour/activities. They are also better motivated and usually undertake difficult tasks more eagerly than people with low self-efficacy (Bandura 1977; Bandura 1997);

4) knowledge of health-related literature, which is essential for empowered patients, as well as the existence of a facilitating environment. The ability to understand and use health-related information to make informed health-related decisions and undertake actions within the healthcare system is of utmost importance (Coulter, Ellins 2007: 24-27; Hohn 1998).

Based on these four components, empowerment can be defined as a process in which patients understand their role, and seek and gain the latest medical knowledge. In addition, they acquire the ability to effectively interact with healthcare staff to perform a specific task in a community that recognises social and cultural differences and encourages patient participation in healthcare activities (WHO 2009).

Today's empowered patient "uses the Internet to acquire knowledge about health-related issues, consults discussion forums, expects high quality services and benefits, is mobile, carefully chooses a physician, an outpatient clinic, hospital" (Dolińska-Zygmunt 2001: 274). Due to their engagement in the process of treatment, such a patient is much less likely to receive poor quality health services (Olesch 2012: 11) mainly because, using the knowledge capital they have accumulated, they know where to seek treatment, receive higher quality services and look for the best specialists. Such a patient accumulates knowledge of how to use the Internet for health purposes (see Łaska-Formejster 2014a: 17-29; Łaska-Formejster 2014b: 186-202). They are also more aware of their rights. As the data show, in Poland 20 years ago, only one fifth of Poles declared they had heard about patient rights and knew their substance (CBOS 2001). This percentage is steadily growing, which proves that Poles' awareness of patient rights is increasing (Sprawozdanie 2015).

The empowered attitude is, on the one hand, the result of patients' distrust in an inefficient, increasingly complex healthcare system. On the other hand, it stems from the desire to draw attention to fundamental patient rights (concerning, for example, subjective treatment, respect for rights in the personal sphere, the right to full medical knowledge about diseases, diagnoses and alternative treatment procedures) (Hallis y 2008: 273-286; Cohen 2010: 6-13). Such a patient is independent, co-responsible for their own health and active on the Internet. 


\section{Online research capacity}

Nowadays, most people (especially in information-driven societies) cannot imagine their life without the Internet. According to 2018 estimates (see Kulik 2018), 4 billion people throughout the world (about 53\% of the total 7.5-billion population) had Internet access. In Poland, $86.7 \%$ of households (about 30 million people) use the Internet (Gemius 2018).

Thus, more widespread use of the Internet opens up new online communication possibilities, defines new research areas, e.g. in social research, and makes it possible to reach new groups of respondents (Gregor, Stawiszyński 2005: 333-334).

The Internet is the most important carrier of civilisational change in the modern world [...]. Thanks to the Internet, there is a radical change in the social space and social context in which an individual find himself. [...] The Internet has become the fullest expression of the postmodern, networked information society (Marody, Batorski, Nowak 2006: 5, 18).

The Internet provides an opportunity for inexpensive ethnography (Kubczak 2002: 185) and ensures respondents' confidentiality, which has a significant impact on the quantity and quality of answers (Marody, Batorski, Nowak 2006: 102). It has been observed that in computer-aided research, respondents more often share private or even intimate information with other people because they have a sense of (also visual) anonymity. They can focus on their own attitudes and emotions, and the very act of writing encourages confessions (Staniszewska 2013: 52).

It has also been noted that the Internet influences behaviour of many social groups:

However, from a social point of view, the phenomenon of the Internet is that it is now much more than just information and communication technology. For many social groups, it has become a natural environment for social functioning that satisfies most social needs and motivations. It is used not only to search for information, but also to make and maintain friendships and close relationships. Moreover, the Internet is also an environment for the establishment of new communities, and social and cultural norms (Zając, Krejtz 2007: 191).

The influence of the Internet on patients' behaviour and activity is therefore worth considering. Certainly, new technological solutions have facilitated the use of medical services to some extent, e.g. through the possibility of electronic registration, obtaining e-prescriptions, or electronic communication with physicians (telemedicine). However, it is noteworthy that not only does the Internet facilitate the patient's contact with healthcare facilities and centres, but increasingly often it also makes the patient refrain from personal contact with a physician. Instead, they seek information about their ailments, symptoms or health on the Internet (the reasons for giving up on personal contacts with a physician are certainly individual and determined by various factors). According to Christine Hine 
(1998), social researchers should react to cultural changes. Thus, if potential respondents move their activity to the Internet, the researcher's task is to reach out to this medium and collect as much data as possible (Jurek 2013: 89).

\section{Sampling and the area of research}

The research project and reflections presented here focus on analysing the perception of autonomy among empowered patients engaged in online activity. The aim was not to scrutinise the use of the notion of autonomy as such, but rather the use of terms referring to its constituent parts. Since the empowered attitude is manifested by the desire to be treated autonomously, subjectively and with respect for personal rights, for the right to full disease-related medical knowledge, full diagnosis and alternative treatment options, it seemed only natural to study these attributes in statements published in medical forums. The answers to the following questions were sought: what components of autonomy do "informed, knowledgeable", empowered patients pay attention to, which components do they recall? How (in their perception) is respect for autonomy manifested in contacts with physicians? And what characteristics of physicians do they pay attention to in descriptions of interactions? Openness, tenacity and courage in publishing their assessments and opinions, without changing their mind under the influence of the statements of other users, are treated as an indicator of the autonomous nature of patients' activity on the analysed portals and medical forums.

Medical portals and forums have thus become an area of research. In order to choose a suitable data collection site, the researcher should be guided by an assessment of adequacy, access to valuable information, the degree of (physical and emotional) risk, ethical considerations and the assessment of social consequences (see Lofland et a1. 2009: 42-60). It was decided that online medical portals/ forums meet the adequacy criterion (and are a "natural" area of activity for empowered patients). The assessment of adequacy is based on the mutual alignment of objectives, research problems and techniques. Web portals visited by people looking for information on medical issues are an appropriate place to search for answers to the indicated questions within the problem area (sample selection was therefore purposive). The use of the selected research technique (content analysis) is suitable for online analysis, and makes it possible to obtain this information.

The research under discussion was carried out in the first quarter of 2019, and only those forums that met the following criteria were included in sampling: active forums with a high number of registered users and entries (which means that users were very active). The research sample (obtained via the Google search engine $^{7}$ ) included 16 medical portals on the following topics: disability, multiple

${ }^{7}$ Key words and their combinations were used for search, e.g. "most popular medical portals", "information search on medical portals", "medical portals on contemporary diseases", "patient seeks 
sclerosis, gynaecology and obstetrics, oncological diseases, mental illnesses, dentistry, eating disorders, allergy, pregnancy and trying to have a baby, cluster headaches, dermatology, heart and cardiovascular diseases, psoriasis, forums for people on dialysis and after kidney transplantation, ophthalmology, and surgery.

In terms of forum users' activity, only manifestations typical of empowered patients were identified and qualified for analysis. Generally speaking, the activity of users of the analysed forums and portals was characterized by such aspects as: sharing personal experiences, opinions and emotions; passing on individually obtained knowledge about diseases and ways to receive help; providing mutual support, or support to the families of patients; or obtaining information. Moreover, expert and advisory statements appeared in many forums. Both patients and specialists provided valuable advice on the symptoms and treatment of diseases, or on coping with everyday life. Internet users exchanged information about good/ competent/recommended specialists, physicians who could help them overcome the disease or improve their quality of life. They also sought information about "good" medical practices. In addition, they exchanged their experience on treatment methods for given diseases, drugs used, their side effects and the treatments they had undergone. Some of the portals contained legal information related to the search for help in the case of a physician having violated patient rights. It is noteworthy that in a few cases patients' complaints about physicians' behaviour and the general functioning of the healthcare system appeared on the web portals.

With reference to earlier reflections and in the context of the results of the analysis presented below, let us define the characteristics of empowered patients that qualify them as study participants. The key selection criterion was their high (and informed) activity on medical portals. In fact, these respondents were active on forums almost every day, sharing the knowledge gained from the Internet and giving advice to other users about physicians, treatment or opinions about medical facilities and the healthcare system (cf. Salmon 2002: 25). Despite the high level of patient activity on medical forums and portals (some of them had several or tens of thousands of registered users), only a few people on each of them could be defined as empowered patients (their activity fluctuated temporarily during the study). Other Internet users undertook a rather pragmatic approach and were active occasionally or intermittently; they treated portals or forums as a source of information. They searched for specific solutions, answers to questions; they rarely participated in discussions, unless they concerned a problem related to their individual situation.

A detailed analysis of user activity revealed that leaders were active almost every day, but the nature of their activity was very diverse and depended on the dynamics of the narrative and needs indicated by other forum users. Therefore,

help on portals", "health forums", "patients and health", "active patients on forums", "most popular health forums", "patient helps on forums", "medical portals - patients most active online". 
there is no methodological justification for recalling figures about this activity. Finally, 127 statements of 31 users - empowered patients - meeting the selection criteria were classified as source material.

Because the results of the preliminary analysis did not reveal separate themes concerning the undertaken subject matter but these themes appeared in the context of descriptions of interactions, the final set of analysed material comprises statements that describe: 1) the motive of the desired pattern of physician-patient relationship, the way physicians communicate with patients, expectations concerning the quality of the assistance they receive, the desired traits of a physician or characteristics cited as attributes of professionalism and competence of the medical personnel. This category also includes statements describing physicians' inappropriate attitudes to patients, indicating a deficit of certain values; 2) statements indicating the authors of the posts have awareness and knowledge of patient rights; 3) statements that contain any of the earlier mentioned attributes of autonomy or its constituent characteristics were also qualified for the analysis. The constituent characteristics include: dignified and benevolent treatment, active involvement in the treatment process, respect for patient rights, e.g. recognition of the right to have one's own views, the right to make one's own choices, providing patients with reliable information, and respect for the principle of intimacy and physician-patient privilege. Even preliminary reflection on selected categories of analysis leads to the conclusion that these statements are not disjointed and mutually exclusive, which determines the area and subject of the study. All of them directly fit into or define the axionormative context of interaction between the medical personnel and the patient.

The presentation of the results of the study should be preceded by a description of the nature and type of the narrative of posted information. Statements qualified as the source research material are mostly laconic, slogan-like, characterised by a lack of care for precise wording and sometimes inconsistency of argumentation. Internet users apply abbreviated and informal linguistic forms (e.g. they refer to others on a first-name basis). They often use slogan-like appeals (e.g. "it is your right, they have to copy the documentation" [statement 43 Gynaecology and Obstetrics]). There are far more descriptive statements (not included in the analysed collection) in which Internet users describe their experience of a disease, their state of health and attempts to improve their quality of life, give practical (almost therapeutic) tips, answer questions about the functioning of facilities run by the National Health Fund, or describe modes of action or procedures, e.g. those needed to obtain a referral for a medical examination without additional explanations. Empathic and friendly statements serve as consolation and reassurance.

Indicators/components of autonomy were finally classified according to the above mentioned (3) categories, since the issues included in the area of research emerged mainly in these contexts. It is also noteworthy that this is a qualitative analysis. Quantitative analysis does not apply here when it comes to statements 
that often supplement previous posts (e.g. "it's your right, you're entitled to it" [statement 49 Surgery]), or confirm previous information ("yes, it's true, first of all ask for a diagnosis and talk about possible treatment options, it's important" [statement 37 Gynaecology]).

\section{Results of the analysis; the components of empowerment identified by an analysis of comments and entries from empowered patients}

Given that the components of the identified research area are almost exclusively referred to in the context of interactions, the interactional frame is the basis for interpreting the final findings. This approach is also justified in the traditional conception of medicine, where the analysis of the physician-patient relationship is the basis for reflecting on the personal qualities of a physician. It was pointed out that the main principle behind the desired interpersonal attitudes was conduct contributing to the satisfaction of an individual's socially accepted needs and avoidance of consequences incompatible with those needs. These interpersonal attitudes include respect for human dignity, subjectivity, respect for health and life, tolerance, care, reliability of information, empathy, and devotion of time and attention to the individual. Satisfying all these needs (which also constitute the value or principle of autonomy) is of particular importance in the process of providing medical care to an individual, whether they are ill or convinced of their illness, or want to eliminate doubts related to their health condition or to monitor it (Czarnecki 2008: 69; Słońska 2010: 64-83; Ostrowska 2010: 23-47; Gałuszka, Legiędź-Gałuszka 2008: 54-106).

The importance of these values is also evidenced by the fact that for more than three decades, ever more information about difficulties encountered in relations between the patient and physician has been described in the literature (e.g. Gordon, Edwards 1999: 106-125, 162-180; Barański 2002: 162-167; Więckowska 2005: 259-266; Łaska-Formej ster 2002: 150-177). Discontent, dissatisfaction, disrespect for patient rights and failure to meet patients' expectations significantly affect the treatment process and the implementation of a physician's recommendations. It can extend the convalescence period, raise doubts as to the competence of the physician, or increase the number of cases of litigation against physicians for their mistakes or for behaviour that violates the rules of the ethical context of interaction.

Entries (recommendations) by Internet users earlier defined as empowered patients with reference to key values or distinctive features of autonomy (i.e. the above-mentioned values and desired attributes of medical interaction) were included in the analysis. However, the preliminary analysis covered a wider range of users' (not only empowered patients') activities, as their response (their statement) fitted a specific narrative context (e.g. a request to indicate a specific course 
of action when the attending physician did not provide any guidance in this respect). In a separate theme of "being treated by a physician who does not provide information, devote enough time to interaction, a diagnosis and justification of the proposed treatment", the authors of the posts most often point out the lack of respect and adherence to the principles inherent in the value of autonomy. Most of the Internet users quote descriptions of "typical" visits in the context of an inquiry posted in the forum to recommend a good physician the internet user is familiar with, because, in their opinion, the one that had so far been providing services either did not have proper qualifications or did not satisfy basic needs and failed to meet minimum expectations. Some of these inquiries were related to situations in which patients learned that they had to use the help of a specialist, but they did not know one, and none was indicated by the analysed attending physician.

Posts containing descriptions of previous visits indicate that their course undermined and contradicted the seemingly universal (in the area of analysed material) respect for fundamental values, principles and rights that should be enjoyed by everyone. These are some examples provided by the analysed Internet users:

- the lack of appropriate, polite and dignified treatment e.g. "loud comments about my appearance (weight) in the presence of the support staff" (Surgery);

- physicians are in a rush, there is not enough time to talk: "no time for anything, he comes late, leaves early, always in a rush - he won't even look you in the eye, only eyedrops, a prescription" (Ophthalmology); "he won't explain anything, he won't say anything - won't say a word, I don't know what's wrong with me" (Allergy);

- jumping to conclusions: “... you certainly didn't take medicine” (Psychiatry);

- criticising: "how can you be so selfish" (Eating disorder);

- referring to a patient in an impersonal manner: "one has to... buys... goes..." (Gynaecology);

- not passing on basic information, e.g. "No information about the diagnosis, just a statement that it'll be fine. It wasn't until the next day that I learned the diagnosis and the expected procedure from another physician" (Ophthalmology);

- abruptness, unfriendliness: "there's nothing human or nice about him, won't even reply to "good morning « and won't repeat himself when you ask him to" (Surgery);

- the lack of respect for rights: “...I can't give you your records” (Surgery);

- a diagnosis made without a detailed interview and examination;

- physicians' unwillingness to agree to additional consultations or specialist examinations and their lack of empathy and care.

And yet the benefit of empathy is mutual: it makes it possible to reach an agreement that enhances trust. An empathic physician becomes more caring, analyses the patient's condition holistically and is able to understand their needs. In turn, the patient, thanks to the established interaction, speaks freely and honestly 
about their feelings, ailments and doubts. The empathic relationship empowers the patient - they become a real human being and not just another case (a classified disease). Empathy makes it possible to establish a relationship that makes the patient's well-being the ultimate good. An empathic physician is a sensitive doctor who uses comprehensible vocabulary, they are responsible, understanding, bringing hope of recovery (Dolińska-Zygmunt 2001: 283-289). It has been proven repeatedly that the very course of physician-patient interaction can have a beneficial therapeutic effect. The physician's personality and positive traits may be an effective treatment for the patient. A friendly atmosphere in the physician's office encourages patient's openness, and facilitates the process of diagnosis and choice of appropriate treatment (Sokołow ska 1986: 91).

Internet users' requests for help and identification of the right professional or facility where they can be found always elicit a positive and fairly quick response. Help, guidance and advice are provided both by active forum leaders (empowered patients, among others) and those who join the discussion later (which constituted a certain analytical difficulty, as some of the statements had to be referred to several times). Quite a characteristic feature of the entries of "leaders" is "not to discuss" and not to comment on the behaviours of doctors in the context of the described negative experiences. And if they do, it is rather in the "objective" tone of the narrative, indicating that, as in any other profession and among physicians, there may be incompetent people or those experiencing difficulties, e.g. "Don't worry and don't take it so personally, after all, he is also a human being, although he shouldn't behave like that [...]" (statement 12 Surgery); "You can come across incompetence in any profession, the most important thing is to get the right treatment now" (statement 13 Ophthalmology); "You're right, such situations shouldn't happen, but slandering Mrs. X is of no use now, let's find a solution" (statement 110 Eating disorders). The leaders try to tone down emotions and offer specific, helpful hints by providing the names of good specialists they know. Sometimes they ask other users, residents of a given location, for information, if the patient has limited mobility. In most of their posts that recommend specialists and medical facilities, the leaders describe physicians' soft skills, emphasising that they treat patients individually and respect their rights, including the right to full medical knowledge about a given disease, full diagnosis and alternative treatment options. Here are examples of such statements:

I recommend doctor $(\mathrm{X})$, she inspires trust, has a great attitude, is warm, cordial, understands the patient's situation and alleviates suffering. She doesn't dismiss you, she talks, explains, is very kind and polite, asks about your needs, mentions different possibilities, shares the results of latest studies in the world (statement 53 Surgery).

Go to (X), no one has helped me like him, an excellent expert, looks into your eyes, he sees you and speaks to you, you understand everything and he repeats and explains things, if necessary. He orders tests, makes sure you can afford medicine and asks whether there is someone to take care of you, he also believes in alternative medicine, you can trust him (statement 97 Neurological diseases). 
Most numerous references to taking care of relations with patients were made on the portal "Pregnancy, trying to have a baby". When recommending a gynaecologist, not only do they describe the desired course of the physician's relationship with the pregnant woman and her family, but also (or rather especially) the personal traits of a recommended physician:

She's warm, kind, patient, competent - you immediately trust her, she is eloquent, looks at a woman's situation holistically, takes into account her capabilities (statement 7 Pregnancy).

Mr. X is a professional, he doesn't stress you, has a nice voice, he's patient, orders the necessary examinations, checks everything, thinks it's better to be safe than sorry, you can be open with him (statement 13 Pregnancy).

He always listened carefully, advised, often wanted me to make the final decision, although he shared his opinion, he would hold your hand if necessary, he is benevolent, knowledgeable about the latest developments, treats you like a human being, asks about and considers various options (statement 29 Pregnancy).

Ensuring the transparency of the results of the analysis of empowered patients' statements requires that traits, qualities, values and principles (which comply with the concept of autonomy, given the context of theoretical considerations) are defined as components of autonomy, catalogued and presented in terms of the following thematic strands:

1) "The course of a physician-(+personnel)-to-patient relationship"; this category includes statements containing descriptions and terms referring to interactions taking place in physicians' offices and hospital wards. According to empowered patients, the following aspects of interactions are particularly important (and mentioned in first place): trustworthiness, respectfulness, professionalism, reliability, a friendly atmosphere, benevolence, humane treatment, respect for dignity, and showing patience and respect for physician-patient privilege. Internet users also point out the constructiveness of the relationship when they write about a physician's proper response to patient's needs and the need to conduct a dialogue. The adjectives used to define the proper course of an interaction include: warm, open, nice, good, as it should be, calm, patient, trusting, caring, comfortable. The ideal attributes refer to situations in which a physician arrives at decisions about treatment together with a patient; explains and agrees the ways to proceed with them.

2) Statements that refer to the characteristics of the conversation, and ways of conveying information are included in the category of "the way physicians communicate with their patients". Empowered patients introduce the following features of communication as components of the desired nature of communication (the researcher is looking for autonomy-related values): comprehensible (clear), factual, slow (in the context of the pace of speech), friendly, "as detailed as possible", "partner-like" ("without showing superiority" [statement 94 Psoriasis]), calm, in no hurry, open to questions, ready to explain 
and illustrate, patient. When referring to the course of patients' conversations with physicians, the leaders pay attention primarily to the friendly but factual tone of the conversation, credibility, trustworthiness and professionalism. There are statements emphasising an individualised approach and the need to make sure that the patient properly understands the information provided ("the physician must make sure that you've understood it properly. After all, there is a fundamental difference between candida and cancer" [statement 13 Oncology]). The importance of a smile during a conversation is mentioned in some entries because "it can be soothing, comforting" [statement $153 \mathrm{Oph}$ thalmology]. This category also includes posts of leaders who give advice and guidance to those users who complain about the lack of opportunity to talk to a physician ("he issues a prescription and that's it" [statement 14 Multiple sclerosis]), lack of information about the diagnosis, therapy and treatment op-tions. They advise:

ask him, you have the right to; ...if you don't understand, ask and demand an explanation; if you don't remember, [...] let Dr. X repeat or write it down; after all, you can prepare your questions beforehand, you won't be nervous about forgetting something; don't be impatient, the physician also needs time to gather his/her its.

They quote descriptions of their own experiences as a form of support and consolation:

I, too, have come across various behaviours. Some of them wouldn't devote more than 5 minutes to you. The examination was short, superficial, and the interview was not too insightful. Something like: "here you're - I'll tell you what's wrong with you, here's a prescription". Some physicians don't like it when you suggest something to them because they treat it as lese-majesty. I've been in contact with a good doctor recently - he asks me questions, he's interested, doesn't dismiss me when I ask something, when I need an explanation. It's nice for a change... and I recommend him (statement 117 Disability forum).

3) "Physician's traits and qualities cited as attributes of professionalism and competence of the medical personnel" is another category identified within the analysed thematic strand. Although the quoted terms have already appeared in previous categories (in the context of interaction), one can come across them in over a dozen posts as more detailed "attributes" of recommended physicians or their desired qualities. Thus, professionalism and competence of a physician and medical staff depend above all on: medical knowledge - reliable, broadly defined (which can be considered a synonym of holistic or interdisciplinary), knowledge of the latest developments and technological achievements in medicine; practical skills ("efficiently performed procedures"; "overcoming difficulties in treatment or surgery"); ability to "keep their cool" (and "...relieve pain and suffering"); professional communication ("a physician's professionalism is manifested in the way they communicate, explain things. Having incredible knowledge, they can illustrate the prob- 
lem and talk about it" [statement 67 Premature baby]); but also benevolence, showing attention, care and empathy ("the professional can understand the patient, maybe not exactly put themselves in your shoes, that would not be too good - but understand you, empathise, feel it" [statement 53 Lung diseases]).

4) The last of the outlined categories is "awareness and knowledge of patient rights". The previous categories also include statements referring to patient rights, e.g. the right to dignified and kind treatment, reliable information, respect for the principle of privacy or physician-patient privilege. There are posts whose authors point to the following patient rights while giving tips, advice and consolation:

the right to dignity, information about treatment, giving consent to treatment, right to intimacy and privacy, physician-patient privilege, the right to be discharged from hospital upon one's request, the right to be visited, the right to a meal, medicines, complaints, the right to confidentiality about the disease and confidentiality of personal data, access to documentation (one's own medical case record), to information about one's own health condition, free treatment throughout the country.

Although not all of these rights are legally regulated, it must be admitted that they intuitively form part of the catalogue of rights that each participant in an interaction - especially of a medical nature - has, and they constitute a convincing argument in favour of the existence and importance of respecting the autonomous values.

\section{Summary}

As has already been indicated, in the context of ethical considerations, attention is paid to values to which an individual is entitled, in their autonomous dimension, e.g. all people have a sense of personal dignity that has to be confirmed, and want empowerment and respect for their rights. Respect for life and health is also one of the fundamental values expressed for example by relief of physical and mental suffering. Have users of medical portals and forums considered them as fundamental in medical interactions?

The results of the analysis made it possible to formulate the thesis that the idea of empowered patients, which emerged partly in response to a lack of trust in the increasingly inefficient healthcare system and out of a desire to draw attention to fundamental patient rights, is reflected in users' activity. In fact, the leaders of the analysed medical forums and portals play the role of "guides" who describe and provide guidance as regards the course of formal pathways and diagnostic procedures. They also share previously acquired knowledge about individual diseases (e.g. by quoting professional publications), point to responsibility for decisions concerning one's own health (through gaining knowledge, implementing appropriate actions and participating in health decisions), and make decisions 
affecting their health (by declaring that they are switching to a healthy lifestyle). On the other hand, in the context of the analysed comments with reference to autonomy, the rights, principles and values of empowered relations are of utmost importance, although they are expressed in a rather colloquial and intuitive manner and knowledge. The concepts of autonomy or subjectivity did not explicitly appear in any of the analysed forums, but a search for these concepts was not the objective of the analysis. The results of the analysis clearly show that the studied Internet users properly understand the notion of autonomy.

When answering the posed problem questions, it should be pointed out that the authors of the analysed posts draw attention to the essential qualities, values and principles that define autonomy and the rights that constitute its fundamentals. The published posts (mostly concerning courses of interactions) contain components of autonomy such as freedom to decide and exercise one's rights; the right not to be influenced = the recognition of the right to have one's own opinions; the right to be treated with respect, dignity and kindness; and the right to receive proper care and attention, which enables empowered actions. It is also noteworthy that Internet users observe these qualities in medical interactions (as a sign of respect for autonomous values) and, whenever necessary, expose their deficit. They attach great importance to the interactional competences of physicians, their qualifications and their ability to provide professional aid. They pay attention to the friendly atmosphere of the visit and the physician's trustworthiness, friendly and caring attitude towards the patient, provision of comprehensive information, and dispelling of doubts (doubts that aggravate fear, suffering and the patient's feeling of loneliness). The fact of publishing opinions on these issues, and not changing opinions under the influence of other users' statements, is treated as an indicator of the autonomous nature of their activity on the analysed medical portals and forums.

\section{Bibliography}

Aring C.D. (1958), Sympathy and empathy, "Journal of American Medical Association”, vol. 167(4), pp. $448-452$.

Atras A., Marczewski K. (2004), Znaczenie świadomej zgody pacjenta na działania medyczne, "Zdrowie Publiczne", no. 114.

Bandura A. (1977), Self-efficacy: toward a unifying theory of behavioral change, "Psychological Review", no. 84(2), pp. 191-215.

Bandura A. (1997), Social Foundations of Thought and Action, Prentice Hall, Englewood CliffsNew York.

Barański J. (2002), Niektóre aspekty komunikowania się lekarza z pacjentem, [in:] J. Barański, W. Piątkowski (eds.), Zdrowie i choroba. Wybrane problemy socjologii medycyny, Oficyna Wydawnicza ATUT - Wrocławskie Wydawnictwo Oświatowe, Wrocław.

Beauchamp T.L., Childress J.F. (1996), Zasady etyki medycznej, transl. W. Jacórzyński, Książka i Wiedza, Warszawa

Brzeziński T. (2002), Etyka lekarska, Wydawnictwo Lekarskie PZWL, Warszawa. 
Bujny J. (2007), Prawa pacjenta. Między autonomia a paternalizmem, Wydawnictwo C.H. Beck, Warszawa.

Business Insider (2020), Zdrowie w sieci. Blisko 50 proc. Polaków szuka w internecie medycznych porad, https://businessinsider.com.pl/technologie/nowe-technologie/medyczne-porady-w-internecie-czego-szukaja-polacy/snd19t3 (accessed 30.06.2020).

CBOS(2001), Wiedzaoprawachpacjenta 2001,http://www.cbos.pl/SPISKOM.POL/2001/K_070_01. PDF (accessed 9.10.2019).

Cohen E. (2010), The Empowered Patient, Ballantine Books Trade Paperbacks, New York.

Coulter A., Ellins J. (2007), Effectiveness of strategies for informing, educating, and involving patients, "The BMJ", no. 335, https://www.researchgate.net/publication/6223140_Effectiveness_of_strategies_for_informing_educating_and_involving_patients (accessed 7.10.2019).

Coulter A., Entwistle V., Gilbert D. (1999), Sharing decisions with patients: is the information good enough?, "The BMJ", no. 318(7179), pp. 318-322.

Czarnecki P. (2008), Dylematy etyczne współczesności, Centrum Doradztwa i Informacji Difin, Warszawa.

Dolińska-Zygmunt G. (ed.) (2001), Podstawy psychologii zdrowia, Wydawnictwo Uniwersytetu Wrocławskiego, Wrocław.

Faden R.R., Beauchamp T.L. (1986), A History and Theory of Informed Consent, Oxford University Press, New York.

Gaertner H. (1997), Lekarz, pacjent, empatia, "Sztuka Leczenia”, vol. 3(3).

Gallagher M.W. (2012a), Self-efficacy, [in:] V.S. Ramachandran (ed.), Encyclopedia of Human Behavior, Academic Press, New York.

Gallagher M.W. (2012b), Self-Efficacy, University of Kansas, Elsevier, Lawrence.

Gałuszka M., Legiędź-Gałuszka M. (2008), Medycyna i zdrowie w społeczeństwie ryzyka, [in:] M. Gałuszka (ed.), Zdrowie i choroba w społeczeństwie ryzyka biomedycznego, Wydawnictwo Uniwersytetu Medycznego, Łódź.

Gemius (2018), Wyniki badania Gemius/PBI za maj 2018, https://www.gemius.pl/wszystkie-artykuly-aktualnosci/wyniki-badania-gemiuspbi-za-maj-2018.html (accessed 27.10.2019).

Gordon T., Edwards W.S. (1999), Pacjent jako partner, transl. T. Szafrański, Instytut Wydawniczy PAX, Warszawa.

Górski A. (ed.) (2012), Leksykon prawa medycznego: 100 podstawowych pojęć, Wydawnictwo C.H. Beck, Warszawa.

Gregor B., Stawiszyński M. (2005), Wykorzystanie Internetu w badaniach panelowych rynku, [in:] M. Sokołowski (ed.), Oblicza Internetu. Internet a globalne społeczeństwo informacyjne, Algraf, Elbląg-Biskupiec.

Hallisy J.A. (2008), The Empowered Patient. Hundreds of life-saving facts, action steps and strategies you need to know, PatientsaftyCA.org., San Francisco.

Hine C. (1998), Virtual Ethnography, http://www.cirst.uqam.ca/pcst3/pdf/Communications/hine. pdf (accessed 27.10.2019).

Hohn M.D. (1998), Empowerment Health Education in Adult Literacy: A guide for public health and adult literacy practitioners, policy makers, and funders, National Institute for Literacy, Laurence.

Jurek K. (2013), Badania społeczne w Internecie. Wirtualna etnografia w teorii i praktyce, "Nauka i Szkolnictwo Wyższe", vol. 1(41), pp. 86-98.

Kalisiewicz D. (ed.) (1995), Nowa encyklopedia powszechna PWN, vol. 1, Warszawa.

Kubczak A. (2002), Cybersocjologia? Internet jako przedmiot zainteresowania socjologów, [in:] L.M. Haber (ed.), Polskie doświadczenia w ksztaltowaniu społeczeństwa informacyjnego, Wydział Nauk Społecznych Stosowanych Akademia Górniczo-Hutnicza, Kraków, pp. 183-190. 
Kubiak R. (2016), Prawo pacjenta do intymności i poszanowania godności. Czesść II, "Medycyna Paliatywna", vol. 8(4).

Kulik W. (2018), Cztery miliardy internautów, http://www.benchmark.pl/aktualnosci/ile-osob-madostep-do-internetu-na-swiecie-juz-ponad-4-miliardy.html (accessed 27.10.2019).

Lofland J., Snow D.A., Anderson L., Lofland L.H. (2009), Analiza układów społecznych, transl. A. Kordasiewicz, S. Urbańska, M. Żychlińska, Wydawnictwo Naukowe Scholar, Warszawa.

Lyons M. (2007), Should patients have a role in patient safety? A safety engineering view, "Quality and Safety in Health Care", https://www.ncbi.nlm.nih.gov/pmc/articles/PMC2653153/ (accessed 24.10.2019).

Łaska-Formejster A. (2002), Proces kształtowania roli zawodowej lekarza rodzinnego, Wydawnictwo Uniwersytetu Łódzkiego, Łódź.

Łaska-Formejster A. (2014a), Pacjenci ery empowered wyzwaniem dla nowych form zarzadzania i strategii marketingowych $w$ ochronie zdrowia, [in:] A. Depta (ed.), Zarzadzanie zdrowiem a problemy społeczeństwa obywatelskiego, Wydawnictwo Politechniki Łódzkiej, Łódź, pp. 17-29.

Łaska-Formejster A. (2014b), Nowoczesne technologie komunikacyjne w systemie opieki zdrowotnej. E-narzędzia i pacjent doby "empowered" a etos zawodu lekarza, [in:] D. Walczak-Duraj (ed.), Praca - rynek pracy - zatrudnienie w perspektywie humanistycznej, "Humanizacja Pracy”, no. 2(276), pp. 186-202.

Łuków P., Pasierski T. (2014), Etyka medyczna z elementami filozofii, Wydawnictwo Lekarskie PZWL, Warszawa.

Marody M., Batorski D., Nowak A. (ed.) (2006), Społeczna przestrzeń internetu, Wydawnictwo Szkoły Wyższej Psychologii Społecznej “Academica”, Warszawa.

Medical Code of Ethics, https://nil.org.pl/uploaded_images/1574857770_kodeks-etykilekarskiej.pdf (accessed 2.02.2020).

Miller R.K., Washington K.D. (2016), Healthcare Business Market Research Handbook 2017-2018, Richard K. Miller \& Associates, Loganville.

Nowacka M. (2005), Autonomia pacjenta jako problem moralny, Wydawnictwo Uniwersytetu w Białymstoku, Białystok.

Olesch A. (2012), Ludzka twarz ochrony zdrowia, "Ogólnopolski System Ochrony Zdrowia", no. 10 , pp. 11-12.

Ossowska M. (1963), Podstawy nauki o moralności, Państwowe Wydawnictwo Naukowe, Warszawa.

Ostrowska A. (2010), Zróżnicowanie społeczne i nierówności w zdrowiu, [in:] W. Piątkowski (ed.), Socjologia z medycyna. W kręgu myśli naukowej Magdaleny Sokołowskiej, Wydawnictwo Instytutu Filozofii i Socjologii Polskiej Akademii Nauk, Warszawa.

Salmon P. (2002), Psychologia w medycynie wspomaga wspótpracę z pacjentem i proces leczenia, transl. M. Gajdzińska, Gdańskie Wydawnictwo Psychologiczne, Gdańsk.

Słońska Z. (2010), Społeczna natura zdrowia: teoria i praktyka, [in:] W. Piątkowski (ed.), Socjologia z medycyna. W kręgu myśli naukowej Magdaleny Sokołowskiej, Wydawnictwo Instytutu Filozofii i Socjologii Polskiej Akademii Nauk, Warszawa.

Sokołowska M. (1986), Socjologia medycyny, Państwowy Zakład Wydawnictw Lekarskich, Warszawa.

Sprawozdanie (2015), Sprawozdanie dotyczace przestrzegania praw pacjenta na terytorium Rzeczypospolitej Polskiej, https://www.rpp.gov.pl/gfx/bpp/userfiles/_public/bip/sprawozdania roczne/sprawozdanie 2014 r. pdf (accessed 3.11.2019).

Staniszewska M. (2013), Internet jako narzędzie prowadzenia badań społecznych, “Acta Innovations", no. 9, pp. 51-57. 
Szewczyk K. (2009), Bioetyka. Medycyna na granicach życia, Wydawnictwo Naukowe PWN, Warszawa.

Szymczak M. (ed.) (1988), Słownik języka polskiego, vol. 1, Państwowe Wydawnictwo Naukowe, Warszawa.

Ustawa z dnia 5 grudnia 1996 r. o zawodach lekarza i lekarza dentysty, tekst jedn. Dz.U. z 2017 r., poz. 125 .

Ustawa z dnia 6 listopada 2008 r. o prawach pacjenta i Rzeczniku Praw Pacjenta, Dz.U. z 2009 r. $\mathrm{Nr} 52$, poz. 417 z późn. zm.

World Health Organisation (WHO) (1998), Health Promotion Glossary, World Health Organization, Geneva, https://www.who.int/healthpromotion/about/HPR\%20Glossary\%201998. pdf?ua=1 (accessed 24.10.2019).

World Health Organisation (WHO) (2009), Guidelines on Hand Hygiene in Health Care: First Global Patient Safety Challenge Clean Care Is Safer Care, World Health Organization, Geneva, https://www.ncbi.nlm.nih.gov/books/NBK144022/ (accessed 24.10.2019).

Wichrowski M. (1992), Spór o autonomię pacjenta, "Medicus", no. 4.

Więckowska E. (2005), Umiejętność komunikowania się jako czynnik ksztattujący efektywność relacji lekarz-pacjent i pacjent-lekarz, [in:] B. Płonka-Syroka (ed.), Relacje lekarz-pacjent w aspekcie społecznym, historycznym i kulturowym, Wydawnictwo DiG, Oficyna Wydawnicza Arboretum, Wrocław-Warszawa.

Zając J.M., Krejtz K. (2007), Internet jako przedmiot i obszar badań psychologii społecznej, "Psychologia Społeczna" vol. 2, 3-4(5), pp. 191-200.

\section{AUTONOMICZNOŚĆ PACJENTA W SIECI - W WYBRANYM OBSZARZE REFLEKSJI TEORETYCZNEJ I ANALIZY EMPIRYCZNEJ}

\footnotetext{
Abstrakt. Celem artykułu jest percepcja pojmowania autonomiczności przez wzmocnionych wiedzą, upodmiotowionych poprzez świadomość odpowiedzialności za własne zdrowie i znajomość przynależnych praw pacjentów (empowered). Owej percepcji dokonano poprzez analizę ich wypowiedzi opublikowanych na 16 forach i portalach internetowych o tematyce medycznej, w których pojawiały się nawiązania do komponentów autonomiczności. Do analizy jakościowej zakwalifikowano 127 postów. Wyniki badania umożliwiły sformułowanie wniosku, że autorzy wpisów autonomiczność (choć nie przywołują tego pojęcia) identyfikują (intuicyjnie) w jej właściwym znaczeniu, zwracając uwagę na pryncypialne jej przymioty, które ją określają, i uprawnienia, które stanowią jej filar. Percypowali oni owe przymioty w przebiegu i cechach interakcji pacjent-personel medyczny (demaskując ich deficyt), w kontekście posiadanych przez uczestników relacji uprawnień i obowiązków oraz w opiniach o kwalifikacjach lekarzy i pożądanych ich kompetencjach (głównie miękkich).

Słowa kluczowe: autonomia, autonomiczność, percepcja autonomiczności, empowered patient, pacjent w sieci, sieć, analiza jakościowa.
} 